\title{
A comparison of some methods of diagnosing Raynaud phenomena of occupational origin
}

\author{
B. HELLSTR $\emptyset M^{1}$ and K. MYHRE \\ International Biological Programme, Human Adaptability Section, Oslo, Norway
}

\begin{abstract}
Hellstrøm, B., and Myhre, K. (1971). Brit. J. industr. Med., 28, 272-279. A comparison of some methods of diagnosing Raynaud phenomena of occupational origin. The aim of the present study was to compare some field methods of diagnosing traumatic vasospastic disease (TVD). Eleven forest workers with TVD (Raynaud phenomena of occupational origin) from the use of chain saws and seven controls underwent various exposures to cold. Sitting naked at 10 to $12^{\circ} \mathrm{C}$ for 40 minutes and exposing the hands to water of 13 to $16^{\circ} \mathrm{C}$ during the last 20 minutes provoked blanching of the fingers of all subjects in the TVD group and in none of the controls. These group differences were only partially supported by skin temperature recordings. Finger cooling during general cold exposure, rewarming after local cold exposures that did not provoke blanching, cold-induced vasodilatation, and rewarming after local vibration in cool water did not differ significantly between the groups. The production of attacks was apparently facilitated by hand grip in the cold. The results underline the diagnostic uncertainties present in those approaches which do not provoke attacks of finger blanching. Such attacks are most easily produced by a combined general and local cold exposure.
\end{abstract}

Traumatic vasospastic disease' (Wright, 1940), TVD, rarely presents symptoms or signs at ordinary room temperature (Jones, 1960). To base the diagnosis solely on the history of attacks is particularly unsatisfactory in a disease which (in many countries) may entitle the patient to workman's compensation. Various types of cold exposure have been applied to verify the diagnosis of TVD in different investigations, but with varying success (see Discussion, p. 276). At present, no single method of diagnosing TVD seems to be generally accepted. The aim of the present study was to compare some simple field procedures of verifying the diagnosis of TVD.

\section{Methods}

Material

Eighteen forest workers were studied (Table 1). Seven workers who denied having Raynaud symptoms served

${ }^{1}$ Correspondence: B. Hellstrøm, M.D., HA/IBP, Grenseveien 99, P.O. Box 6094-Etterstad, Oslo 6, Norway. as controls. Eleven workers had repeatedly experienced blanching and numbness of the fingers on cold exposure over the last 2 to 10 years (TVD group). No symptoms had been observed between attacks. All fingers were reportedly affected in five subjects. In the rest of the subjects, from two to nine fingers were said to be diseased (Fig. 1). Subsequent case histories about six months after the initial examination confirmed this point completely. The symptoms were attributable to the use of chain saws (Grounds, 1964). Except for the TVD, the subjects were healthy, as judged from a general clinical examination. Tactile two-point discrimination ad modum (Mackworth, 1953) did not indicate sensory impairment, and trophic lesions of the fingers were not present.

\section{Procedures}

Exercise, heavy meals, and exposure to uncomfortable temperatures were avoided for 2 hours before the experiments, which were made in field laboratories in November. Experiments started at 8 a.m. and 1 p.m.; subjects studied in the morning in one series were studied in the afternoon in the other and vice versa. The subjects, wearing nylon shorts only, and with the hands below heart level, sat in pairs (usually one control and one from the TVD group) 
TABLE 1

Experimental Subjects: Mean Values \pm S.D. and (Range) of Some Relevant Parameters

\begin{tabular}{|c|c|c|c|c|c|c|c|c|c|c|c|}
\hline Group & $N$ & $\begin{array}{l}\text { Age } \\
(y r)\end{array}$ & $\begin{array}{l}\text { Height } \\
(\mathrm{cm})\end{array}$ & $\begin{array}{c}\text { Weight } \\
(\boldsymbol{k g})\end{array}$ & Right & Left & $\begin{array}{c}B S R \\
(\mathrm{~mm} / \mathrm{hr})\end{array}$ & $\stackrel{H b}{(g / 100 ~ m l)}$ & Systolic & Diastolic & $\begin{array}{l}\text { Occupied in } \\
\text { forestry } \\
(y r)\end{array}$ \\
\hline TVD & 11 & $\begin{array}{r}36 \pm 9.6 \\
(22-53)\end{array}$ & $\begin{array}{l}173 \pm 7 \cdot 4 \\
(157-183)\end{array}$ & $\begin{array}{c}69 \cdot 0 \pm 5 \cdot 0 \\
(61 \cdot 2 \pm 78 \cdot 5\end{array}$ & $\begin{array}{r}532 \pm 40 \\
(455-605)\end{array}$ & $\begin{array}{r}531 \pm 55 \\
(449-633)\end{array}$ & $\begin{array}{l}3 \pm 0.9 \\
(1-10)\end{array}$ & $\begin{array}{r}15 \cdot 6 \pm 1 \cdot 2 \\
(14 \cdot 5-16 \cdot 4)\end{array}$ & $\begin{array}{r}135 \pm 27 \\
(110-150)\end{array}$ & $\begin{array}{c}85 \pm 9 \\
(70-100)\end{array}$ & $\begin{array}{c}19 \pm 9 \cdot 2 \\
(7-40)\end{array}$ \\
\hline
\end{tabular}

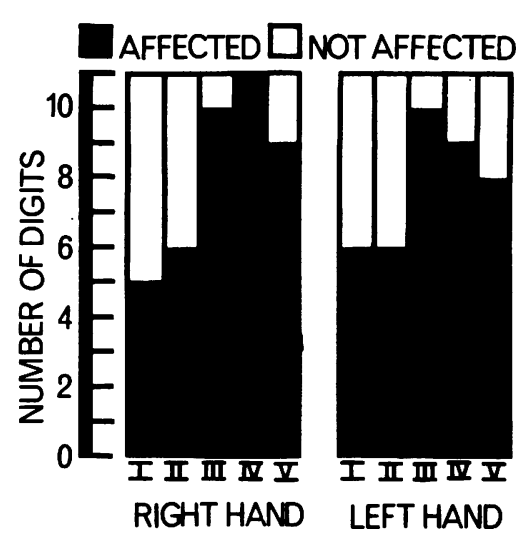

FIG. 1. Distribution of Raynaud phenomena in 11 workers with TVD.

in either a 'warm room' (air temperature $\left(T_{A}\right)=30$ to $32^{\circ} \mathrm{C}$ ) or a 'cool room' $\left(\mathrm{T}_{\mathrm{A}}=10\right.$ to $\left.12^{\circ} \mathrm{C}\right)$. Wall temperatures varied within the range of air temperatures, relative humidity between 40 and $60 \%$ and air movement from 10 to $20 \mathrm{~cm} / \mathrm{second}$. Both series started in the warm room, where the subjects first rested for 30 minutes (while the thermocouples were fastened and initial tem- peratures recorded) and then immersed their hands in warm water (Table 2) for 15 minutes. In the first series the subjects remained in the warm room, immersing both hands successively in cool and cold water (Table 2) for 20 minutes. Each local exposure was followed by 1 minute gentle drying on a bath towel and 20 minutes rewarming in ambient air. In the second series the subjects were transferred to the adjacent cool room where they first rested for $\mathbf{2 0}$ minutes with dry hands, then exposed their hands to cool water (Table 2) for 20 minutes, and finally rested for 15 minutes with wet hands. The subsequent 20 minutes' rewarming with dry hands in the warm room ended the experiment for one subject. The other subject now exposed his hands to cool water (Table 2) for 10 minutes (three subjects for 20 minutes) while squeezing hand dynamometers at about $8 \mathrm{kp}$ force. During the last 5 minutes (three subjects for 10 minutes) the left dynamometer vibrated vertically at 55 to $77 \mathrm{~Hz}$ and $(\bar{x} \pm$ S.E.) $3.5 \pm 0.22 \mathrm{~mm}$ amplitude. The hands were finally dried and rewarmed for 20 minutes.

\section{Measurements}

Temperatures were measured by copper-constantan thermocouples (with reference junctions in melting ice) and multipoint potentiometer recorders (Speedomax W, and W AZAR, Leeds \& Northrup, Philadelphia). Measurements were taken of the skin temperature $\left(T_{s}\right)$ close to the base of the nail of all fingers and (in one series) medially at mid-thigh, as well as rectal temperature $\left(T_{r}\right)$

TABLE 2

Water Temperatures $\left({ }^{\circ} \mathrm{C}\right):$ Mean Values \pm S.E.M.

\begin{tabular}{|c|c|c|c|c|c|c|}
\hline \multirow{3}{*}{$\begin{array}{l}\text { Environment, general: } \\
\text { Environment, local }\end{array}$} & \multicolumn{5}{|c|}{ Warm room } & \multirow{3}{*}{$\begin{array}{c}\text { Cool room } \\
\text { Cool }\end{array}$} \\
\hline & \multirow[b]{2}{*}{ Warm } & \multirow[b]{2}{*}{ Cool I } & \multirow[b]{2}{*}{ Cold } & \multicolumn{2}{|c|}{ Cool $I^{1}$} & \\
\hline & & & & Right & Left & \\
\hline Initial temp. $\quad$. & $43 \cdot 7 \pm 0 \cdot 2$ & $16.4 \pm 0.2$ & $3 \cdot 3 \pm 0.2$ & $16 \cdot 0 \pm 0.3$ & $16 \cdot 3 \pm 0 \cdot 2$ & $13.5 \pm 0.2$ \\
\hline Final temp. $\quad$.. & $41 \cdot 3 \pm 0 \cdot 2$ & $20.4 \pm 0.2$ & $8.2 \pm 0.2$ & $16.7 \pm 0.4$ & $16.9 \pm 0.3$ & $15 \cdot 3 \pm 0.4$ \\
\hline
\end{tabular}

${ }^{1}$ Hand grip and vibration added. 
$10 \mathrm{~cm}$ inside the anus. Skin thermocouples were covered by one layer of adhesive tape (Norgesplaster). The accuracies were within $\pm 0.3^{\circ}$ and $\pm 0.1^{\circ} \mathrm{C}$ for $T_{s}$ and $T_{r}$, respectively.

Heat output from the hand was measured by modified Stewart (1911) calorimeters of 4 litres volume and water equivalents of from 200 to $265 \mathrm{ml}$. The temperature $\left(T_{w}\right)$ of the vigorously stirred water was recorded by thermopiles, suppressing an appropriate part of the total thermoelectric emf by millivolt potentiometers (Leeds \& Northrup, model 8686) and recording the remaining signal on a Speedomax H, 0-1 mV, multipoint recorder. Hand volumes were measured by water displacement. The accuracy of the calorimetric method was estimated at $\pm 10 \mathrm{cal} / \mathrm{min} / 100 \mathrm{ml}$ hand tissue. The calibration of the thermoelectric equipment was checked twice daily.

Oxygen uptake $\left(\mathrm{Vo}_{2}\right)$ was measured at the ends of the initial warm and general cold exposures of the second series, using Douglas bags and Scholander's $0.5 \mathrm{ml}$ apparatus.

Vibrations were monitored by an accelerometer and an audio-frequency spectrometer with level recorder (Brüel \& Kjær, Copenhagen).

\section{Results}

\section{General thermal state of the body}

Mid-thigh $\mathrm{T}_{\mathbf{s}}$, an estimate of mean skin temperature (Teichner, 1958), was initially ( $\bar{x} \pm$ S.E.) $33 \cdot 6 \pm$ $0.5^{\circ} \mathrm{C}$ in the TVD group and $32.6 \pm 1.0^{\circ} \mathrm{C}$ in the controls. Neither this temperature nor the $T_{r}$ (Table 3) indicated significant group differences of the total body thermal state. Moderate shivering occurred towards the end of the stay in the cold room, but $\mathrm{Vo}_{2}$ increased significantly $(\mathrm{P}<0.01)$ only in the TVD group (Table 4).

\section{Heat output from the hands}

The calorimetric method did not pick up any significant group differences (Table 5).

\section{Rewarming after local cold exposure}

The fingers of two subjects in the TVD group were wax coloured after local cold exposure in the warm room. The local cool exposure provoked no
TABLE 4

Oxygen Consumption: Mean Values \pm S.E.M. (ml/min STPD)

\begin{tabular}{|c|c|c|c|c|c|}
\hline \multicolumn{3}{|c|}{ Group } & $N$ & Warm room & Cool room \\
\hline $\begin{array}{l}\text { TVD } \\
\text { Control }\end{array}$ & $\begin{array}{l}. \\
\ldots\end{array}$ & $\begin{array}{l}. \\
\ldots\end{array}$ & $\begin{array}{r}11 \\
7\end{array}$ & $\begin{array}{l}333 \pm 12 \\
413 \pm 18\end{array}$ & $\begin{array}{l}400 \pm 20 \\
445 \pm 52\end{array}$ \\
\hline
\end{tabular}

symptoms in this environment. The rewarming curves revealed no group differences after either exposure (Fig. 2).

\section{Cold-induced vasodilatation}

An increase of $\mathrm{T}_{\mathrm{s}}-\mathrm{T}_{\mathrm{w}}$ larger than $0.5^{\circ} \mathrm{C}$ was used as the criterion for a cold-induced vasodilatation (CIVD) (Lewis, 1930) during local cold exposure in the warm room. CIVD occurred more frequently in TVD-affected subjects (Table 6; 0.05 > P > 0.02). The characteristics of the reaction did not differ significantly between the groups (Table 7). Low occurrence and generally small reactions in normal fingers indicated that the conditions were not optimal for eliciting CIVD.

\section{TABLE 5}

Average Rate of Heat Output from Hands DURING LAST 16 MinUtes of Calorimetry: MEAN VAlues \pm S.E.M. (cal $/ \mathrm{min} / 100 \mathrm{ml}$ haND TISSUE)

\begin{tabular}{l|l|l|r|r|c}
\hline \multirow{2}{*}{ Group } & \multirow{2}{*}{ Hand } & $N$ & \multicolumn{2}{|c|}{ Warm room } & Cool room \\
\cline { 3 - 6 } & & & Cool water & Cold water & Cool water \\
\hline TVD $^{1}$ & Right & 9 & $88 \pm 8$ & $93 \pm 9$ & $34 \pm 3$ \\
& Left & 9 & $85 \pm 8$ & $104 \pm 7$ & $28 \pm 2$ \\
\hline Control & Right & 7 & $77 \pm 8$ & $101 \pm 12$ & $30 \pm 3$ \\
& Left & 7 & $76 \pm 12$ & $96 \pm 13$ & $29 \pm 2$ \\
\hline
\end{tabular}

${ }^{1}$ Recordings lost in two subjects.

TABLE 3

Rectal Temperatures $\left({ }^{\circ} \mathrm{C}\right):$ Mean Values \pm S.E.M.

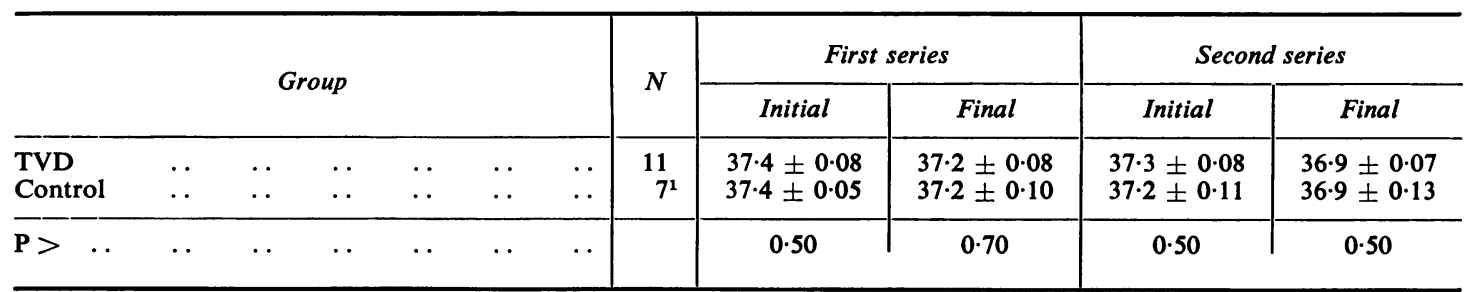

${ }^{1} \mathrm{~N}=6$ in the first series. 


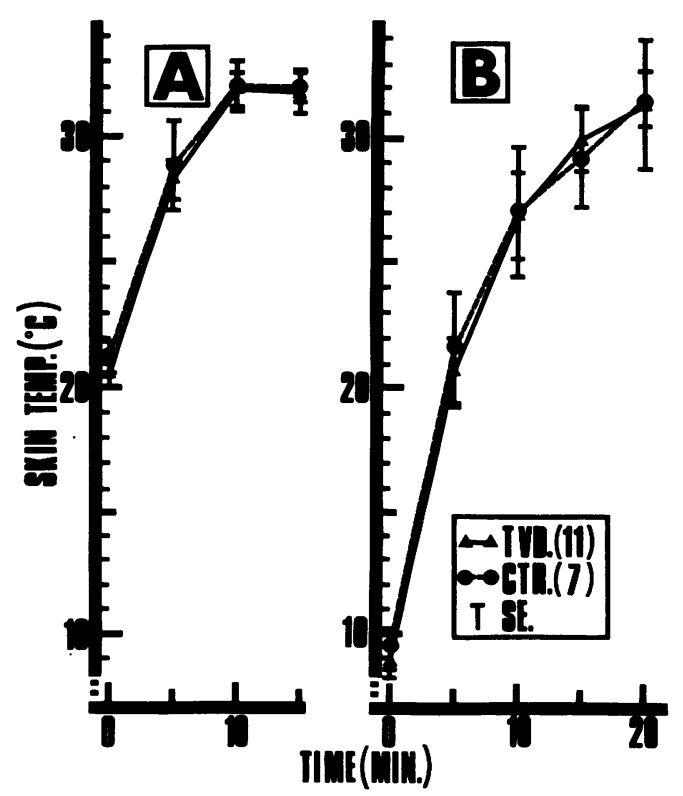

FIG. 2. Skin temperatures of right fourth finger during rewarming from (A) local cool and (B) local cold exposure in a warm room.

\section{Combined effect of general and local cold}

During the initial general cold exposure the fingers affected with TVD did not blanch but tended to attain lower temperatures than did normal ones (Fig. 3). The temperature differences were not statistically significant, however.

On withdrawal of the hands from the cool water, blanching of the fingers occurred in every subject of the TVD group but in none of the controls. The diagnosis was verified by simple inspection, but the

TABLE 6

OCCURRENCE OF COLD-INDUCED VAsodilatation (CIVD) DURING LOCAL COLD EXPOSURE IN A WARM ROOM

\begin{tabular}{l|l|c|c|c}
\hline \multirow{2}{*}{ Group } & \multirow{3}{*}{ Fingers } & \multicolumn{2}{|c|}{ No. of fingers } & \\
\cline { 3 - 4 } & & $\begin{array}{c}\text { With } \\
\text { CIVD }\end{array}$ & $\begin{array}{c}\text { Without } \\
\text { CIVD }\end{array}$ & $\begin{array}{c}\text { CIVD } \\
(\%)\end{array}$ \\
\hline TVD $^{1}$ & Affected & 51 & 24 & 68 \\
TVD $^{1}$ & Unaffected & 10 & 5 & 67 \\
Control $^{3}$ & Unaffected & 35 & 32 & 52 \\
\hline
\end{tabular}

${ }^{1} \mathrm{~N}=9$, recordings lost in two subjects. ${ }^{2} \mathrm{~N}=7$, recordings lost in three fingers.
TABLE 7

Characteristics OF Cold-induced Vasodilatation: Mean Values \pm S.E.M. for All Fingers WITHIN EACH CATEgORY

\begin{tabular}{|c|c|c|c|c|}
\hline Category & $N$ & $\begin{array}{c}\text { Time of } \\
\text { onset } \\
(\mathrm{min})\end{array}$ & $\begin{array}{c}\text { Peak } \\
\text { time } \\
\text { (min) }\end{array}$ & $\begin{array}{c}\text { Temp. } \\
\text { increase } \\
\left({ }^{\circ} \mathrm{C}\right)\end{array}$ \\
\hline $\begin{array}{l}\text { TVD, affected } \\
\text { fingers } \\
\text { TVD, unaffected } \\
\text { fingers } \\
\text { Controls }\end{array}$ & $\begin{array}{l}51 \\
10 \\
35\end{array}$ & $\begin{array}{l}7 \cdot 5 \pm 0 \cdot 4 \\
7 \cdot 7 \pm 1 \cdot 1 \\
5 \cdot 8 \pm 0 \cdot 6\end{array}$ & $\begin{array}{l}13 \cdot 2 \pm 0.4 \\
13 \cdot 9 \pm 1 \cdot 1 \\
10 \cdot 7 \pm 0.7\end{array}$ & $\begin{array}{l}1 \cdot 9 \pm 0.1 \\
1 \cdot 5 \pm 0.2 \\
1 \cdot 1 \pm 0 \cdot 1\end{array}$ \\
\hline
\end{tabular}

changes varied considerably between affected fingers. The blanching frequently gave way to a moderate greyish cyanosis before the subject entered the warm room. The digital pallor promptly reappeared, however, with a light grip of the raised hand in the cold (as when steadying the respiratory valve). The two subjects whose fingers had blanched previously on local cold exposure in the warm room retained pallid and numb fingers for 10 to 20 minutes after their return to the warmth. In the rest of the TVD group, the symptoms disappeared after a few minutes in this environment.

Thumbs affected with TVD remained colder than unaffected ones in the cool room $(0.05>P>0.02)$. The same trend was present in the other fingers but fell short of statistical significance (Fig. 4).

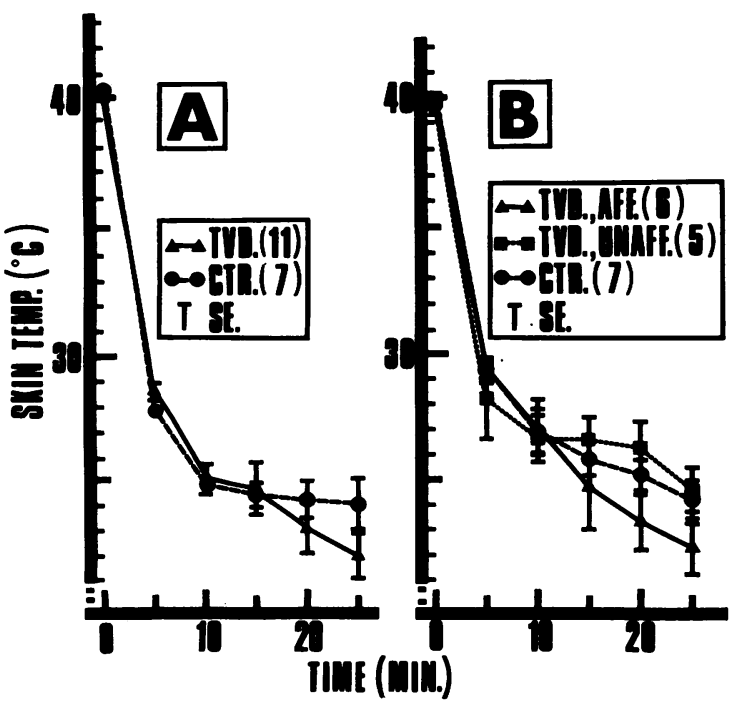

FIG. 3. Skin temperatures of (A) right fourth finger and (B) left thumb during first part of general cool exposure. 


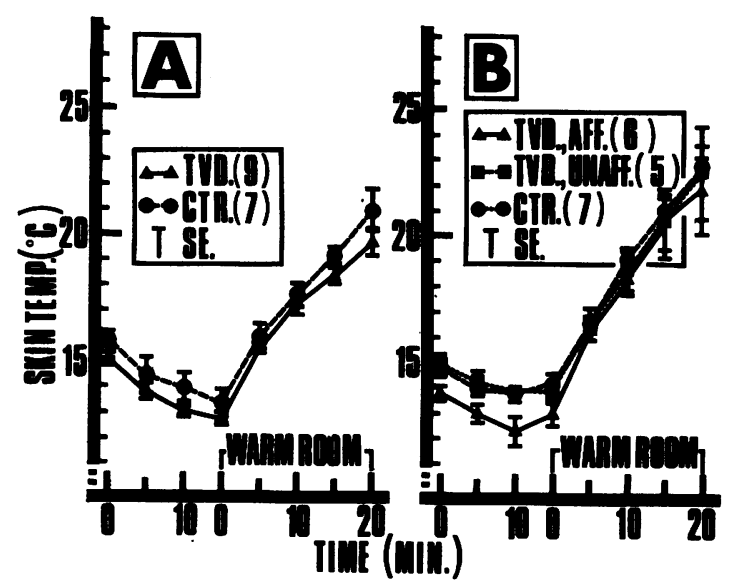

FIG. 4. Skin temperatures of (A) right fourth finger and (B) left thumb during rewarming after combined general and local cool exposure.

\section{Effect of hand grip and vibration}

In two subjects with TVD the fingers of both hands blanched. The pallor disappeared after about 10 minutes, but numbness persisted for the remainder of the experimental period. Normal fingers warmed to somewhat higher temperatures than did fingers affected with TVD, the difference being most marked on the vibrated side (Fig. 5). The finger skin temperatures did not reach normal values in the course of 20 minutes, possibly because the subjects were still in some heat debt.

\section{Discussion}

\section{Effect of total body cold exposure}

The general cold exposure caused only a statistically insignificant trend towards more marked finger cooling in patients with TVD than in the controls. These results are in keeping with our earlier findings in this field (Hellstrøm and Vik, 1970) and do not contradict the concept that subjects with TVD exhibit an increased vasoconstriction in the fingers on total body cooling. However, the 'gross exaggeration of normal constrictive vascular responses' (Ashe and Williams, 1964) that leads to blanching or cyanosis of the fingers apparently required considerably more drastic general cold exposures than the present (Ashe, Cook, and Old, 1962). The interindividual variation in finger cooling during total body cold exposure is normally considerable. There is also a possibility that occupational vibration may increase the local constrictor response to cold before full-fledged TVD appears (Kylin and Lidström, 1968; Hellstrøm and Vik, 1970). General cold exposures, which, like the present, fall short of pro-

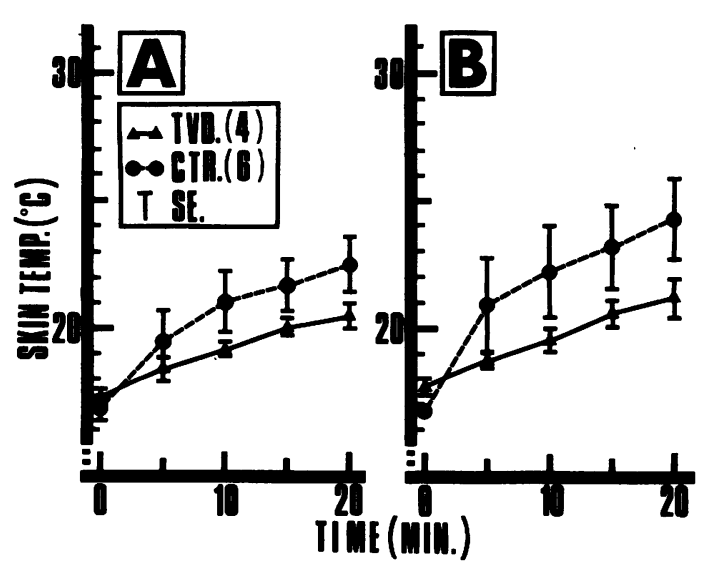

FIG. 5. Skin temperatures of (A) right and (B) left middle fingers during rewarming after combined local cool exposure and hand grip with added vibration of left hand.

voking attacks of Raynaud phenomena, seem to be of dubious diagnostic value in TVD.

Effect of moderate local cooling in generally warm subjects

Hand blood flow reaches its minimum in water of about 12 to $15^{\circ} \mathrm{C}$ (Spealman, 1945), which temperature has been advocated as optimal for provoking attacks of Raynaud phenomena (Hillestad, 1959). This approach has produced quite different results in various groups of subjects with TVD. Ejrup and Sjöström (1955) immersed the hands and forearms of 15 'pounding up' machine operators with TVD in $15^{\circ} \mathrm{C}$ water for 10 minutes (air temperature $23.0^{\circ}$ to $27.8^{\circ} \mathrm{C}$ ) and observed a distinct blanching or cyanotic discoloration of the affected fingers. Agate (1949) had 21 women and 163 men with TVD from the use of a portable rotating tool immerse their hands and forearms in running water at $15^{\circ} \mathrm{C}$ for 15 minutes and obtained positive results in 7 women and $111 \mathrm{men}$. The area of disturbance shown in the test, however, never appeared as extensive as that described in the case histories. Treiberg, Utbult, Lund, and Plevin (1964) had forest workers with TVD, sitting lightly clothed at $20^{\circ} \mathrm{C}$ for 15 minutes, immerse both hands in $15^{\circ} \mathrm{C}$ water for 5 minutes. No attack of Raynaud phenomena was observed. A similar approach $\left(30\right.$ minutes rest at $20^{\circ} \mathrm{C}$ air temperature and 10 minutes immersion of one hand in water of $10^{\circ} \mathrm{C}$ ) was used in 43 chain saw users by Takagi (1968). No sizable difference in cooling effect could be traced between the group with Raynaud phenomena and the controls. The present results were also negative in this respect. Heat output from the hands of both patients with TVD and controls 
was low, indicating a markedly reduced hand blood flow, but did not reveal group differences of diagnostic value. No attacks of blanching occurred, and it thus seems unlikely that methods more sensitive than the present calorimetry for measuring hand or finger blood flow could have provided a diagnosis of TVD under the prevailing thermal conditions. The discrepancies among earlier findings using this approach may have been due to different degrees of severity of TVD in the various subjects. Also the general thermal environmental conditions used do not exclude the possibility that some subjects have been in heat debt.

Effect of intense local cooling in generally warm subjects

The fact that the fingers of two subjects blanched during this procedure is not quite in agreement with the classical observation of Hunt (1936) that 'When their bodies are really warm, it is impossible to produce an attack, no matter how cold their hands are.' Failing in 9 out of 11 patients, and being rather painful, this approach cannot be advocated as a means of diagnosing TVD, however.

\section{Cold-induced vasodilatation}

The cold-induced vasodilatation (CIVD) (Lewis, 1930) can be elicited in the fingers of subjects with Raynaud's disease (Hertzman and Roth, 1942; Hillestad, 1959; Thompson, 1959). In patients with TVD, however, CIVD has been reported to be markedly reduced or completely absent (Magos and Okos, 1963). Under the present thermal conditions, no evidence was found of an impaired CIVD in subjects with TVD. In a later study of forest workers with TVD, CIVD was present just as frequently, and not less markedly in affected fingers as compared with unaffected ones (Hellstrøm and Vik, 1970). These results indicate that the reported slight affection of A-V anastomoses in TVD (Pellegrini, Martines, Musacci, Antonioli, and Longhini, 1966) is either a late feature of the disease or of minor functional importance. The diagnostic value of CIVD in mild cases of TVD seems dubious, as does the hypothesis (Magos and Okos, 1963) that the attack of blanching is due to an impaired CIVD.

\section{Rewarming after local cold exposure}

A delayed finger rewarming after local cold exposures which have (Ejrup and Sjöström, 1955) or have not precipited attacks of blanching (Anda, 1960 ) has been reported in patients with TVD. Other studies have failed in this respect (Treiberg et al., 1964). Such rewarming curves, apparently obtained under less strictly standardized thermal and metabolic conditions than the present, have even been used as a basis for grading the severity of TVD (Anda, 1960). In the present study, the finger re- warming of patients with TVD did not differ significantly from that of the controls. The conflicting results in this field may be due to different degrees of vascular affection in the various groups studied.

\section{Effect of combined general and moderate local cold exposure}

This approach accomplished our main goal: provocation of attacks of blanching of the fingers in all subjects with TVD. Similar methods have been used by Davies, Glaser, and Collins (1957) and by Kylin and Lidström (1968) and have been recommended for provoking attacks in Raynaud's disease (Shepherd, 1963). This type of approach is strongly favoured by the present results, which are in keeping with the well-established clinical experience that Raynaud phenomena are most likely to occur in subjects who are in heat debt (Hunt, 1936; Bruusgaard, 1941; Telford, McCann, and MacCormack, 1945; Agate, 1949).

It is not surprising that in the cool room skin temperatures differed little between blanched wet fingers and wet fingers of the control group, since finger blood flow must normally be minimal in this thermal situation. Plethysmography, as used by Kylin and Lidström (1968), might have detected the small differences of blood flow between blanched and maximally constricted normal fingers, but the comparison of symmetrical affected and nonaffected fingers used by these authors was possible for only 4 out of the 80 affected fingers in the present subjects.

\section{Effect of hand grip}

The results indicate that a hand grip in the cold to some extent enhances the provocation of attacks. This is in keeping with our own clinical experience and that of others (Seyring, 1930; Ponhold, 1943; Agate, 1949). The mechanism is not clear. A sustained hand grip one-fifth of maximal markedly reduced finger blood flow (Rohter and Hyman, 1962) and thus must aid local cooling, i.e., it may have an effect similar to that attributed to the neurogenic cold vasoconstriction in attacks of Raynaud's disease (Shepherd, 1963).

\section{Effect of short-term vibration}

It has been almost unanimously agreed that Raynaud phenomena are provoked by cold and not by vibration per se, but Williams and Riegert (1961) have reported some cases in which vibration apparently was the main trigger. By combining whole body cooling with hand grip, local cold exposure, and local vibration, Ashe and Williams (1964) were able to produce attacks of Raynaud phenomena in two subjects suffering from TVD. The extent and severity of blanching seemed to be maximal. Driving a cold car on a dirt road was a main trigger of attacks in 
several of our subjects, as it has been in other studies (Williams and Riegert, 1961; Grounds, 1964). The contribution of local vibration in combination with general and local cold exposure, plus hand grip, is hard to evaluate, however. According to Magos (1961), acute vibration increases the heat content of normal fingers but not of those affected with TVD. This effect was hardly discernible in the present results, which do not favour local vibration in the cold as a means of detecting Raynaud phenomena of occupational origin.

\section{General comment}

The pathophysiology of TVD is not fully known (review by Jones, 1960). The wide variety of supplementary diagnostic procedures including cold exposure or vibration fall into two distinct categories - those that provoke attacks of blanching and those that do not. Considerable uncertainty appears to be inherent in the latter type of procedure. The vascular response to cold, and possibly to vibration, in the finger is normally subject to a considerable interand intraindividual variation which makes it difficult, if not impossible, to define an exact border between normal and pathological reactions. These difficulties can be reduced but hardly ever eliminated by a strict standardization of the experimental conditions. Adequate standardization of metabolic and thermal conditions is difficult to achieve in the field, however, and is inevitably very time-consuming. Provoking attacks of finger blanching circumvents these problems. In Raynaud's disease "the difficulty in inducing attacks at will is well known' (Shepherd, 1963). In TVD, the present results strongly indicate that Raynaud phenomena are easiest to provoke by a combined general and local cold exposure. To determine whether the verified Raynaud phenomena are of occupational origin or are caused by some of the many other conditions which may produce similar signs (e.g., Jepson, 1951), the thorough medical examination, including a detailed case history, still seems indispensable.

\section{References}

Agate, J. N. (1949). An outbreak of cases of Raynaud's phenomenon of occupational origin. Brit.J. industr. Med., 6, 144-163.

Anda, B. (1960). Forekomsten av vasospastiske forstyrrelser ('hvite fingrer') blant gruvearbeidere i Sulitjelma. Nord. hyg. T., 41, 123-147.

Ashe, W. F., Cook, W. T., and Old, J. W. (1962). Raynaud's phenomenon of occupational origin. Arch. environm. Hlth, 5, 333-343.

, and Williams, N. (1964). Occupational Raynaud's II. Further studies of this disorder in uranium mine workers. Arch. environm. Hlth, 9, 425-433.

Bruusgaard, A. (1941). Om optreden av angionevrotiske forstyrrelser i hendene ('døde hender') hos bankere $i$ skotøyindustrien. Nord. hyg. T., 22, 209-318.

Davies, T. A. L., Glaser, E. M., and Collins, C. P. (1957).
Absence of Raynaud's phenomenon in workers using vibratory tools in a warm climate. Lancet, 1, 1014-1016.

Ejrup, B., and Sjöström, B. (1955). Raynaud's phenomenon in machine operators. Nord. Med., 53, 985-990.

Grounds, M. D. (1964). Raynaud's phenomenon in users of chain saws. Med. J. Aust., 1, 270-272.

Hellstrøm, B., and Vik, T. (1970). 'White fingers' in Norwegian forest workers. A clinical and experimental study. Preliminary report. Tidsskrift for Skogbruk. No. 1, 105116.

Hertzman, A. B., and Roth, L. W. (1942). The vasomotor components in the vascular reactions in the finger to cold. Amer. J. Physiol., 136, 669-679.

Hillestad, L. K. (1959). The peripheral circulation during exposure to cold in normals and in patients with the syndrome of high-titre cold haemagglutination. Acta med. scand., 164, 203-218.

Hunt, J. H. (1936). Raynaud's phenomenon in workmen using vibrating instruments. Proc. roy. Soc. Med., 30, 171-178.

Jepson, R. P. (1951). Raynaud's phenomenon-a review of the clinical problem. Ann. rov. Coll. Surg. Engl., 9, 35-51.

Jones, W. A. (1960). Vibration Injury from Hand Tools-a Critical Review. Thesis, Ohio State University, Athens, Ohio.

Kylin, B., and Lidström, I.-M. (1968). Undersökning över vibrationsskador hos skogsarbetare. In Hälso-och miljöundersökning bland skogsarbetare. Edited by B. Kylin, G. Gerhardson, E.-E. Hansson, I.-M. Lidström, B. Liljenberg, §. Swensson, and I. Åstrand, pp. 44-62. Arbetsmedicinska Institutet, Stockholm.

Lewis, T. (1930). Observations upon the reactions of the vessels of the human skin to cold. Heart, 15, 177-208.

Mackworth, N. H. (1953). Finger numbness in very cold winds. J. appl. Physiol., 5, 533-543.

Magos, L. (1961). Preliminary communication: a physiological study of the effects of vibration on the fingers. Brit. J. industr. Med., 18, 157-158.

_ phenomenon. Arch. environm. Hlth, 7, 402-410.

Pellegrini, R., Martines, G., Musacci, G., Antonioli, G. and Longhini, C. (1966). Prime osservazioni sugli aspetti ultrastrutturali del circolo preterminale nella microangiopatia da strumenti vibranti. Arcisped. S. Anna Ferrara, 19, 443-455.

Ponhold, J. (1943). Zur Frage der weissen Hände bei Blechspannern und Schleifern. Arch. Gewerbepath. Gewerbehyg. $12,102-111$.

Rohter, F. D., and Hyman, C. (1962). Blood flow in arm and finger during muscle contraction and joint position changes. J. appl. Physiol., 17, 819-823.

Seyring, M. (1930). Erkrankungen durch Arbeit mit Pressluftwerkzeugen. Arch. Gewerbepath. Gewerbehyg., 1, 359375.

Shepherd, J. T. (1963). Physiology of the Circulation in Human Limbs in Health and Disease, p. 279. Saunders, Philadelphia.

Spealman, C. R. (1945). Effect of ambient air temperature and of hand temperature on blood flow in hands. Amer. J. Physiol., 145, 218-222.

Stewart, G. N. (1911). Studies on the circulation in man. I. The measurement of the bloodflow in the hands. Heart, 3, 33-75.

Takagi, S. (1968). Raynaud's phenomenon due to chain saw and chipping machine. Jap. Circulat. J., 32, 99-110.

Teichner, W. H. (1958). Assessment of mean body surface temperature. J. appl. Physiol., 12, 169-176.

Telford, E. D., McCann, M. B., and MacCormack, D. H. (1945). 'Dead hand' in users of vibrating tools. Lancet, 2, 359-360.

Thompson, I. D. (1959). Vasospasm and cold. Irish J. med. Sci., 6th series, no. 402, 267-273. 
Treiberg, B., Utbult, B., Lund, F., and Plevin, E. (1964). Effects of Power Saw Vibrations on Forest Workers. Department of Operational Efficiency, Royal College of Forestry. Res. Note No. 22, Stockholm.
Williams, N., and Riegert, A. L. (1961). Raynaud's phenomenon of occupational origin in uranium miners. Occup. Hlth Rev., 13, no. 4, pp. 3-8.

Wright, I. S. (1940). Industrial medicine-and its relation to peripheral vascular disease and injury. Industr. Med., 9, 460-471.

Received for publication July 6, 1970. 